\title{
Bicruciate retaining total knee arthroplasty : results throughout history
}

\author{
Jef De Mulder, Pieter Berger, Hilde Vandenneucker
}

From the Orthopaedic department of UZ Leuven, Belgium

Approximately $20 \%$ amongst patients are dissatisfied after total knee arthroplasty (TKA). Bicruciate retaining (BCR) TKA offers superior knee kinematics and proprioception, but many surgeons abandoned its use because of complications and technical difficulties. Recently, two new BCR implant designs were introduced: Vanguard XP (Zimmer Biomet) and Journey XR (Smith\&Nephew).

We searched Pubmed, Limo, Embase and Cochrane, screened reference lists of eligible studies and included studies that met the inclusion criteria. We included 35 articles reporting on ten different BCR implants, including three articles presenting results of the Vanguard XP prosthesis. Unfortunately, no articles reporting on the results of the Journey XR prosthesis had been published.

The BCR implants of the early 1970s showed good functional results, but a high rate of complications, mainly loosening and infections. The Townley Anatomic TKA was the first BCR implant with good clinical results, a low incidence of loosening and a high survivorship. One article of the three reporting on the Vanguard XP yielded high patient satisfaction (94\%) with two revisions $(1.4 \%)$. The two other articles reported three revisions (5\%) after one year of follow-up and 19 revisions (13.4\%) after three years of follow-up.

Throughout history, the functional results of BCR TKA improved, with lessening of the complications. The short-term results of the Vanguard XP implant showed good functional results, but two out of three articles reported a high rate of loosening. Based on the results reported in this review, the use of BCR TKA is still debatable. Further high-level evidence research is necessary to assess the clinical benefit of BCR TKA.
Keywords: Bicruciate retaining; total knee arthroplasty ; Vanguard XP.

\section{INTRODUCTION}

The first mentions of any type of knee arthroplasty in literature, were resection and interposition arthroplasty in the late 1800s. In the 1940s, the first knee hemiarthroplasties were performed (1). The "modern" era of total knee arthroplasty (TKA) started with the introduction of hinged knee prostheses in the 1950s. These led to the rotatinghinged knee prosthesis, which is nowadays mostly used in revision, tumor and cases with a high risk of instability (2).

The implants developed in the 1970s provided a foundation for the concepts and technologies used today. There were two philosophies to approach TKA. The anatomic approach wanted to mimic the native knee as closely as possible by preserving both cruciate ligaments and as much soft tissue as possible. The functional approach preferred function and

Jef De Mulder,

Pieter Berger,

- Hilde Vandenneucker

Orthopaedic department of UZ Leuven, Belgium.

Correspondence : Jef De Mulder, Herestraat 49, 3000 Leuven, Belgium.

Email : jef.demulder@student.kuleuven.be

- 2021, Acta Orthopædica Belgica. 
mechanics over anatomy. This approach simplified the mechanics of the knee by resecting the condyles and the cruciate ligaments. BCR implants adhere to the anatomic approach while most of the current TKAs follow the functional approach because of its simplicity and reliable results $(3,4)$.

Though historically, TKA was indicated in the elderly population, we recently see a demographic shift to the younger, more active patients which is accompanied with new challenges (5). Numerous articles have reported a dissatisfaction of approximately 20\% amongst patients who undergo TKA (6). Furthermore, a relatively high number of young patients yielded residual symptoms and their prosthetic knee did not feel normal (7). This could be explained by the abnormal kinematics of posterior cruciate retaining (CR), cruciate sacrificing or substituting (CS) and posterior stabilized (PS) implant designs. These designs sacrifice the anterior cruciate ligament (ACL), in contrast to the BCR TKA. The sacrifice of the ACL may affect proprioception, ligament tension and muscle moment arms (8). This intuitively feels wrong, especially when an intact ACL has been shown to be present in $60-80 \%$ of arthritic knees (9).

ACL retention may generate superior knee kinematics and proprioception, causing improved function, stability and satisfaction (10). By lessening the stress transmitted through the prosthesis, BCR TKA could theoretically improve implant longevity. Conversely, there is evidence against using the BCR TKA based on a more challenging surgical technique, difficulty with ligament balancing, and debatable evidence of the true benefit of ACL retention. Moreover, BCR TKA showed a high rate of loosening throughout history. Therefore, the BCR implant design has not been used widely, even though studies have showed the patients' preference for BCR TKA. A study by Pritchett reported a higher preference of the BCR TKA compared to the PS TKA, although the relief from pain, range of movement (ROM), stability and alignment did not differ (11).

As a result of the complications and difficulties, surgeons started using the CR and PS design in the 1980s because of their surgical simplicity and implant longevity. Shortly after, Townley reported promising clinical results with a BCR TKA. Despite these results, the surgical technique and failures (especially of the Geometric knee) discouraged surgeons from using the BCR TKA (12).

Recently, two new BCR TKA designs were introduced: Vanguard XP (Zimmer-Biomet) and Journey XR (Smith\&Nephew). The goal of this article is to compare the results of different BCR TKA implant designs and to evaluate whether the clinical results of these two recent designs have improved compared to older BCR implant designs.

\section{METHODS}

We performed a search for articles on the electronic databases Pubmed, Embase, Cochrane and Limo (from as soon as they were electronically available until October 2019). One person performed the search (JDM), while one reviewer supervised the search method (HV). Several search methods were used. First, articles were identified using a combination of the following keywords : "bi(-)cruciate retaining", "bi(-)cruciate preserving", "arthroplasty", "total knee arthroplasty", "total knee replacement". Secondly, we screened these articles for names of BCR implant designs, which were used to search for more articles. The following designs were used as keywords with and without the previous keywords: Polycentric, Geometric, Geomedic, Kodama-Yamamoto, Duocondylar, Mark I, Mark II, LCS, Townley Anatomic, Cloutier non-constrained, Hermes 2C, Search, Journey XR and Vanguard XP. Finally, the references of the eligible studies were screened for additional articles that were not previously found.

Prospective and retrospective studies of any BCR implant design were included. Any study which reported new findings of a BCR TKA was included. Articles did not have to exclusively report on BCR TKA, however the article had to report the results of the BCR implant separately. Some of the following outcome parameters had to be reported on to be included : Range of Motion (ROM), stability, pain, mobility, use of walking aids, satisfaction, survivorship and complications.

Abstract-only articles were excluded, as well as studies that did not make a distinction between 


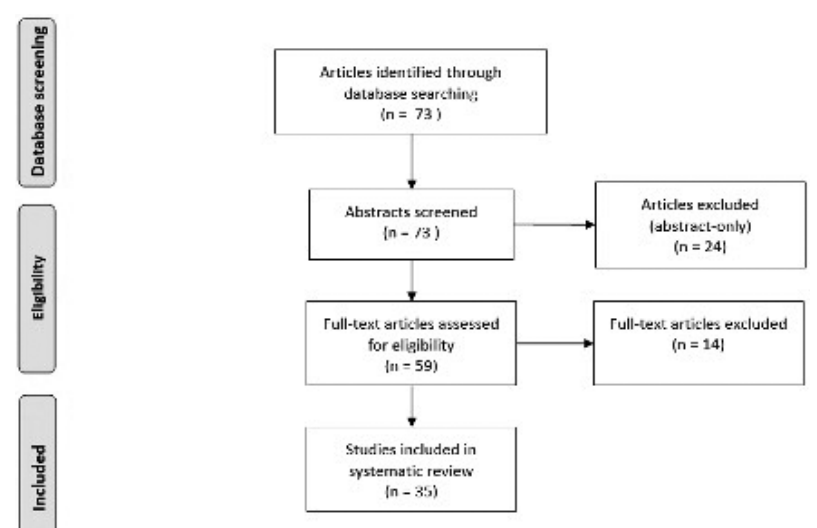

Figure 1. - Flow diagram

Table I. - Number of articles per design

\begin{tabular}{|l|c|}
\hline Design & Number of article \\
\hline Polycentric & 12 \\
\hline Geomedic & 9 \\
\hline Kodama-Yamamoto Mark II & 2 \\
\hline Townley Anatomic & 2 \\
\hline Cloutier non-constrained & 2 \\
\hline LCS & 2 \\
\hline Search & 1 \\
\hline Hermes 2C & 2 \\
\hline Vanguard XP & 3 \\
\hline
\end{tabular}

BCR implants and others in the results. Systematic reviews were checked for more information, but since they do not introduce new results, they were excluded. Articles in other languages than the English language were excluded.

The original search yielded 73 articles. Full text was not available for 24 articles, these were therefore excluded. After additional screening of the articles, 14 more articles were excluded. Finally, 35 articles were included in our study (figure 1). Table I shows the number of articles reporting on each implant. The results are reported separately for each prosthesis, in chronological order.

This article reports on nine different implants. The Geomedic prosthesis (or Geometric I) later evolved into the Geometric II prosthesis. In literature, these names are both used independently. In this article, the Geometric and Geomedic prosthesis will be referred to as the Geomedic prosthesis.

While discussing the results in our tables, we refer to studies with short-term and long-term follow-up time. In this study, a short-term follow-up is defined as a follow-up of less than three years on average. Long-term follow-up is defined as more than three years of follow-up on average.

Unfortunately, we did not find results for every BCR implant. We found one article reporting on the surgical technique of the Journey XR TKA and briefly on their first clinical results (13). The article did not report any objective clinical results and was therefore excluded.

\section{RESULTS}

Twelve articles of the included literature reported on the Polycentric TKA (table II) (14-25). This implant was developed by Dr. Gunston in the early 1970s and was the first BCR TKA. The short-term follow-up studies of the Polycentric knee indicated satisfactory relief of pain was achieved, and functional capacity was significantly increased. Nevertheless, all studies reported a high rate of complications ( $>10 \%$ after two years, $34 \%$ after ten years). The short-term studies (eight articles) showed a high rate of loosening (1.8\%-10\%) in four articles and a high rate of infections $(2 \%-7 \%)$ in five articles (14-21). Dislocations and fractures were also common complications, especially in more active patients. These complications may be the consequence of the inexperience of surgeons, as they can be caused by malalignment, insufficient cementing, imprecise fitting and inadequate placement in inadequate bone. However, studies concerning the Polycentric knee reported no significant learning curve. The long-term follow-up studies reported a progressive deterioration of the functional outcomes and survivorship of Polycentric TKA. All four reported a high rate of loosening (4.2\%-7\%) (22-25). Lewallen et al. reported a survivorship of $66 \%$ after ten years (24).

Bloom and Bryan used a variant, the Widetrack Polycentric knee, to decrease the incidence of loosening using flat-surfaced tibial components that cover more area of the tibial surface. While it appears to be effective, the incidence of lateral subluxation increased (21).

Although good clinical results were achieved with the Polycentric knee, they also encountered 
Table II. — Results of the Polycentric prosthesis (ROM : Range of Motion ; OA : Osteoarthritis ; RA : Rheumatoid Arthritis)

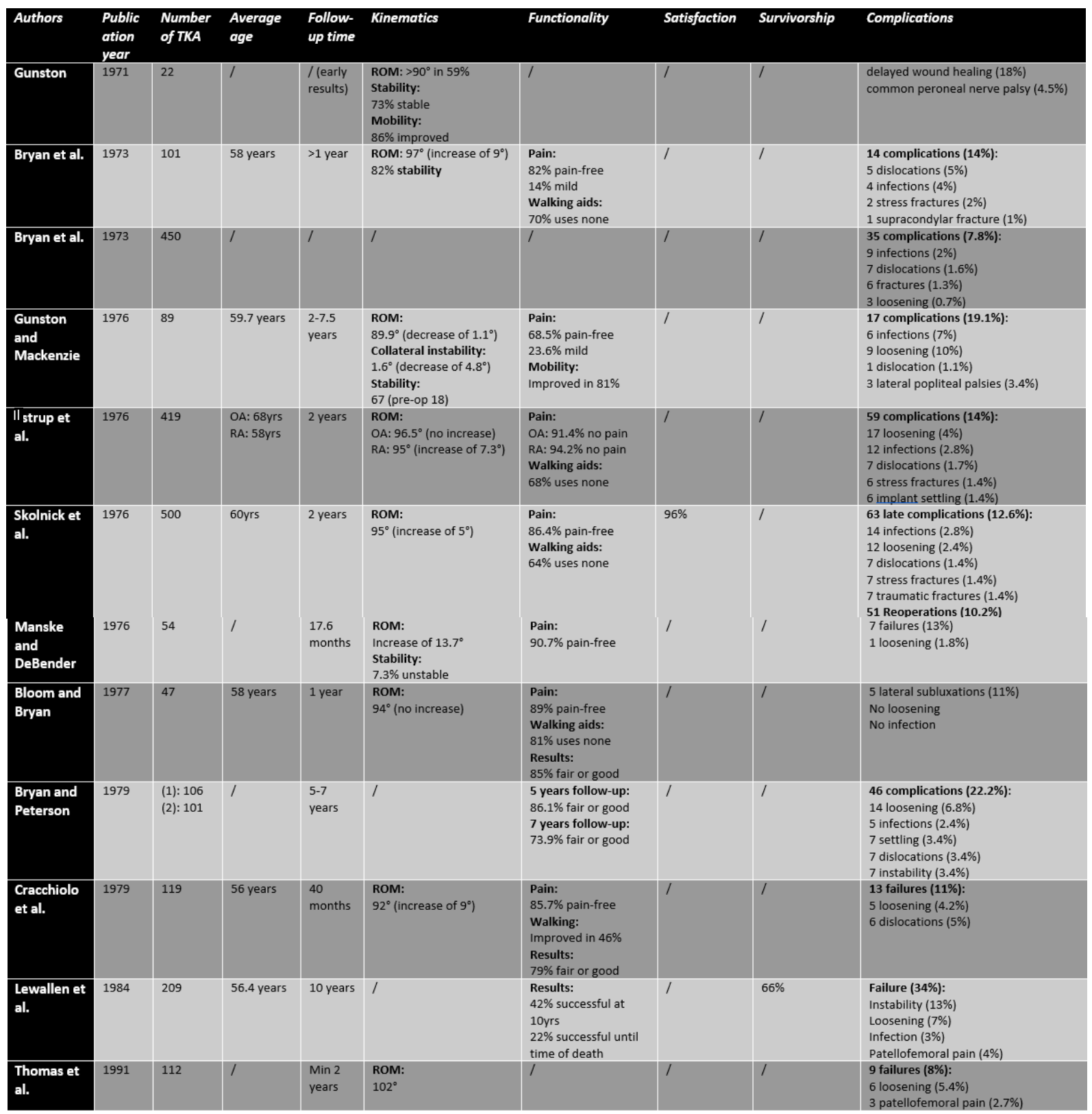

several problems. The unreplaced patellofemoral joint was painful and the placement of four separate components was technically demanding and did not consistently allow satisfactory corrections of deformities, which caused a high incidence of complications.

The Kodama-Yamamoto prosthesis (table III) was developed at around the same time as the Polycentric prosthesis $(26,27)$. Two articles reported on the next generation of this prosthesis : Mark II. They reported good functional results, but with a high amount of loosening (4.5\%) in the study with the longest follow-up (two to seven years). Despite using a scoring system, the long-term follow-up study did not report the average score.

The Geomedic prosthesis later evolved to the Geometric II prosthesis (23,28-35). The design was developed at the Mayo Clinic in 1971. Results (table 
Table III. - Results of the Kodama-Yamamoto prosthesis

(ROM : Range of Motion ; Niwa, Terayama, Yamamoto Knee function scoring system)

\begin{tabular}{|c|c|c|c|c|c|c|c|c|c|}
\hline Authors & $\begin{array}{l}\text { Public } \\
\text { ation } \\
\text { year }\end{array}$ & $\begin{array}{l}\text { Number } \\
\text { of TKA }\end{array}$ & $\begin{array}{l}\text { Average } \\
\text { age }\end{array}$ & $\begin{array}{l}\text { Follow- } \\
\text { up time }\end{array}$ & Kinematics & Functionality & Satisfaction & Survivorship & Complications \\
\hline $\begin{array}{l}\text { Yamamoto } \\
26\end{array}$ & 1979 & 127 & 1 & 1 year & 1 & $\begin{array}{l}\text { Pain: } \\
93.4 \% \text { mild or none } \\
\text { Results (Niwa, } \\
\text { Terayama, } \\
\text { Yamamoto): } \\
74 \text { points (increase of } \\
36 \text { points) }\end{array}$ & 1 & 1 & $\begin{array}{l}5 \text { Complications (5.5\%): } \\
1 \text { infection ( } 1 \%) \\
0 \text { loosening }\end{array}$ \\
\hline $\begin{array}{l}\text { Yamamoto } \\
\text { et al. }{ }^{27}\end{array}$ & 1989 & 350 & I & $2-7$ years & $\begin{array}{l}\text { ROM: } \\
\text { Flexion: } 96.5^{\circ}\end{array}$ & $\begin{array}{l}\text { Results (Niwa, } \\
\text { Terayama, } \\
\text { Yamamoto): } \\
83 \% \text { excellent or good }\end{array}$ & I & I & $\begin{array}{l}31 \text { Complications }(9.9 \%) \text { : } \\
3 \text { infections ( } 1 \%) \\
14 \text { loosening }(4.5 \%) \\
7 \text { pain }(2.2 \%) \\
4 \text { Instability }(1.3 \%) \\
3 \text { Restriction of movement ( } 1 \%)\end{array}$ \\
\hline
\end{tabular}

Table IV. - Results of the Geomedic prosthesis (ROM : Range of Motion ; OA : Osteoarthritis ; RA : Rheumatoid Arthritis)

\begin{tabular}{|c|c|c|c|c|c|c|c|c|c|}
\hline Authors & $\begin{array}{l}\text { Public } \\
\text { ation } \\
\text { year }\end{array}$ & $\begin{array}{l}\text { Number } \\
\text { of TKA }\end{array}$ & $\begin{array}{l}\text { Average } \\
\text { age }\end{array}$ & $\begin{array}{l}\text { Follow- } \\
\text { up time }\end{array}$ & Kinematics & Functionality & Satisfaction & Survivorship & Complications \\
\hline $\begin{array}{l}\text { Coventry } \\
\text { et al. }\end{array}$ & 1973 & 317 & / & $\begin{array}{l}\text { / (early } \\
\text { results) }\end{array}$ & I & $\begin{array}{l}\text { Impossible to } \\
\text { evaluate at this stage }\end{array}$ & 1 & 1 & $\begin{array}{l}32 \text { Complications }(10.1 \%) \text { : } \\
4 \text { loosening }(1.3 \%) \\
3 \text { dislocation }(0.9 \%) \\
3 \text { instability }(0.9 \%)\end{array}$ \\
\hline $\begin{array}{l}\text { Ilstrup et } \\
\text { al. }\end{array}$ & 1976 & 75 & $\begin{array}{l}60.5 \\
\text { years }\end{array}$ & 2 years & $\begin{array}{l}\text { ROM: } \\
\text { OA: } 87.8^{*} \text { (increase of } \\
1.2^{*} \text { ) } \\
\text { RA: } 75.8^{*} \text { (increase of } \\
7.5^{*} \text { ) }\end{array}$ & $\begin{array}{l}\text { Pain: } \\
\text { OA: } 85 \% \text { mild or none } \\
\text { RA: } 92 \% \text { mild or none } \\
\text { Walking aids: } \\
\text { OA: } 60 \% \text { uses none } \\
\text { RA: } 32 \% \text { uses none }\end{array}$ & 1 & I & $\begin{array}{l}8 \text { loosening }(10.7 \%) \\
1 \text { dislocation }(1.3 \%)\end{array}$ \\
\hline $\begin{array}{l}\text { Skolnick et } \\
\text { al. }\end{array}$ & 1976 & 110 & 61 years & 2 years & $\begin{array}{l}\text { ROM: } \\
\left.80^{\circ} \text { (decrease of } 2^{*}\right)\end{array}$ & $\begin{array}{l}\text { Pain: } \\
92 \% \text { mild or none } \\
\text { Walking aids: } \\
49 \% \text { uses none }\end{array}$ & $93 \%$ & I & $\begin{array}{l}17 \text { reoperations (15.5\%): } \\
10 \text { loosening (9\%) } \\
2 \text { infections (1.8\%) } \\
2 \text { pain and decreased motion (1.8\%) }\end{array}$ \\
\hline $\begin{array}{l}\text { Cracehiolo } \\
\text { et al. }{ }^{33}\end{array}$ & 1979 & 92 & 66 years & $\begin{array}{l}41 \\
\text { months }\end{array}$ & $\begin{array}{l}\text { ROM: } \\
96^{*} \text { (increase of } 8^{4} \text { ) }\end{array}$ & $\begin{array}{l}\text { Pain: } \\
85.7 \% \text { mild or none } \\
\text { Walking: } \\
27 \% \text { improvement } \\
\text { Results: } \\
77.9 \% \text { fair to good }\end{array}$ & I & I & $\begin{array}{l}15 \text { failures }(16 \%): \\
9 \text { loosening }(9.3 \%) \\
4 \text { infections }(2.7 \%) \\
1 \text { dislocation }(0.7 \%)\end{array}$ \\
\hline $\begin{array}{l}\text { Hunter et } \\
\text { al. }{ }^{31}\end{array}$ & 1981 & 150 & 60 years & 3 years & $\begin{array}{l}\text { ROM: } \\
\text { No change }\end{array}$ & $\begin{array}{l}\text { Pain: } \\
81 \% \text { better } \\
58 \% \text { pain-free } \\
\text { Use of walking aids: } \\
34 \% \text { improved } \\
\text { Climbing stairs: } \\
41 \% \text { improved }\end{array}$ & I & I & $\begin{array}{l}18 \text { failures }(122 \%) \text { : } \\
14 \text { late sepsis }(9.3 \%) \\
2 \text { instability (1.3\%) } \\
1 \text { infection }(0.7 \%) \\
1 \text { retropatellar pain }(0.7 \%)\end{array}$ \\
\hline $\begin{array}{l}\text { Riley and } \\
\text { Woodyard } \\
32\end{array}$ & 1985 & 71 & 61 years & $\begin{array}{l}\text { Max } 8.5 \\
\text { years }\end{array}$ & $\begin{array}{l}\text { ROM: } \\
14 \% \text { increase } \\
\text { Deformity: } \\
14 \% \text { (decrease of } 60 \% \text { ) }\end{array}$ & $\begin{array}{l}\text { Pain: } \\
72 \% \text { better } \\
\text { Walking time: } \\
33 \% \text { better }\end{array}$ & I & $\begin{array}{l}\mathbf{8 1 . 7 \%} \text { (endpoint: } \\
\text { revision / severe } \\
\text { pain) }\end{array}$ & Failures (18.3\%) \\
\hline $\begin{array}{l}\text { Ivarsson et } \\
\text { al.". }\end{array}$ & 1986 & 122 & 62 years & $\begin{array}{l}58 \\
\text { months }\end{array}$ & $\begin{array}{l}\text { ROM: } \\
\text { OA: } 90 \% \text { with }>90^{\circ} \\
\text { RA: } 96 \% \text { with }>90^{\circ} \\
\text { Mediolateral stability: } \\
\text { OA: } 93 \% \\
\text { RA: } 89 \%\end{array}$ & $\begin{array}{l}\text { Pain: } \\
\text {-At rest: } 87 \% \text { pain- } \\
\text { free } \\
\text { - weight-bearing: } \\
72 \% \text { pain-free } \\
\text { Walking aids: } \\
\text { OA: } 65 \% \text { use none } \\
\text { RA: } 37 \% \text { use none }\end{array}$ & $\begin{array}{l}61 \% \text { very } \\
\text { satisfied } \\
32 \% \text { satisfied } \\
7 \% \text { not } \\
\text { satisfied }\end{array}$ & I & Loosening with pain (12\%) \\
\hline $\begin{array}{l}\text { Rand and } \\
\text { Coventry }\end{array}$ & 1988 & 193 & 69 years & 11 years & $\begin{array}{l}\text { ROM: } \\
96^{\circ} \text { (increase of } 4^{\prime \prime} \text { ) }\end{array}$ & $\begin{array}{l}\text { Pain: } \\
82.8 \% \text { mild to none } \\
\text { Walking aids: } \\
59.1 \% \text { uses none }\end{array}$ & I & $\begin{array}{l}69 \% \text { (endpoint: } \\
\text { revision / severe } \\
\text { pain) } \\
78 \% \text { (endpoint } \\
\text { without revision }\end{array}$ & \\
\hline $\begin{array}{l}\text { Van Loon } \\
\text { et al. }\end{array}$ & 1993 & 189 & $\begin{array}{l}60.6 \\
\text { years }\end{array}$ & 11 years & $\begin{array}{l}\text { ROM: } \\
100^{\circ} \\
\text { Mediolateral stability: } \\
68 \% \text { stable }\end{array}$ & $\begin{array}{l}\text { Pain: } \\
70 \% \text { pain-free } \\
\text { Walking aids: } \\
51 \% \text { uses none }\end{array}$ & I & $\begin{array}{l}78 \% \text { at } 13 \text { years } \\
\text { (endpoint: } \\
\text { implant-removal) } \\
58 \% \text { at } 13 \text { years } \\
\text { (endpoint: } \\
\text { implant-removal / } \\
\text { radiographical } \\
\text { loosening) }\end{array}$ & $\begin{array}{l}34 \text { revisions }(18 \%) \text { : } \\
18 \text { loosening }(9.5 \%) \\
3 \text { retropatellar pain }(1.6 \%) \\
5 \text { Pain of unknown origin }(2.6 \%) \\
5 \text { infection }(2.6 \%) \\
3 \text { instability }(1.6 \%)\end{array}$ \\
\hline
\end{tabular}

IV) showed it relieved pain adequately, improved function and rehabilitated the patient. The shortterm results showed at least $10.1 \%$ of all knees had complications, mainly loosening and infections.
At the early stages of using this prosthesis, they reported a decrease of the complications as their experience increased. 
Table V. - Results of Townley Anatomic prosthesis (ROM : Range of Motion ; AKSS : American Knee Society Score)

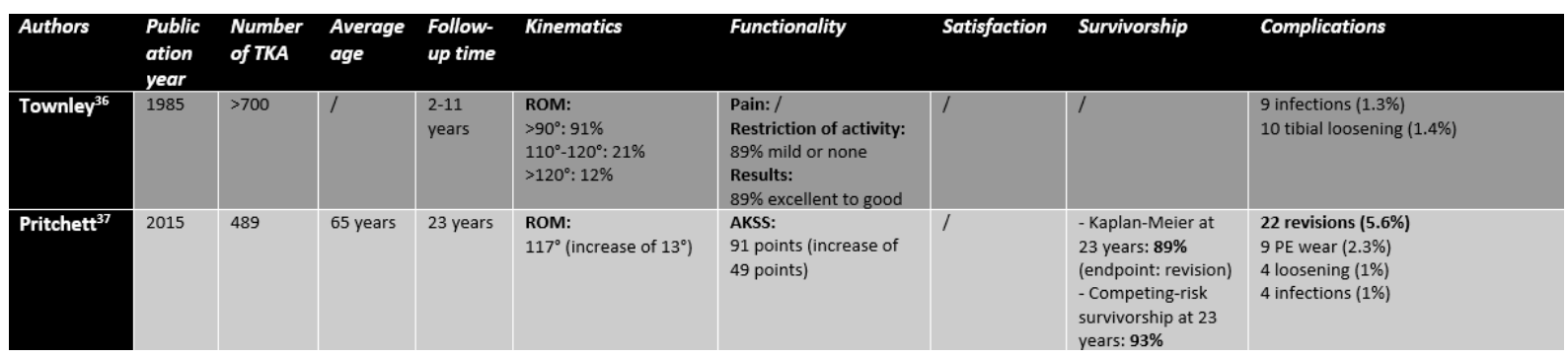

Table VI. - Results of Cloutier Non-Constrained prosthesis

ROM : Range of Motion ; HSS : Hospital for Special Surgery Knee Score)

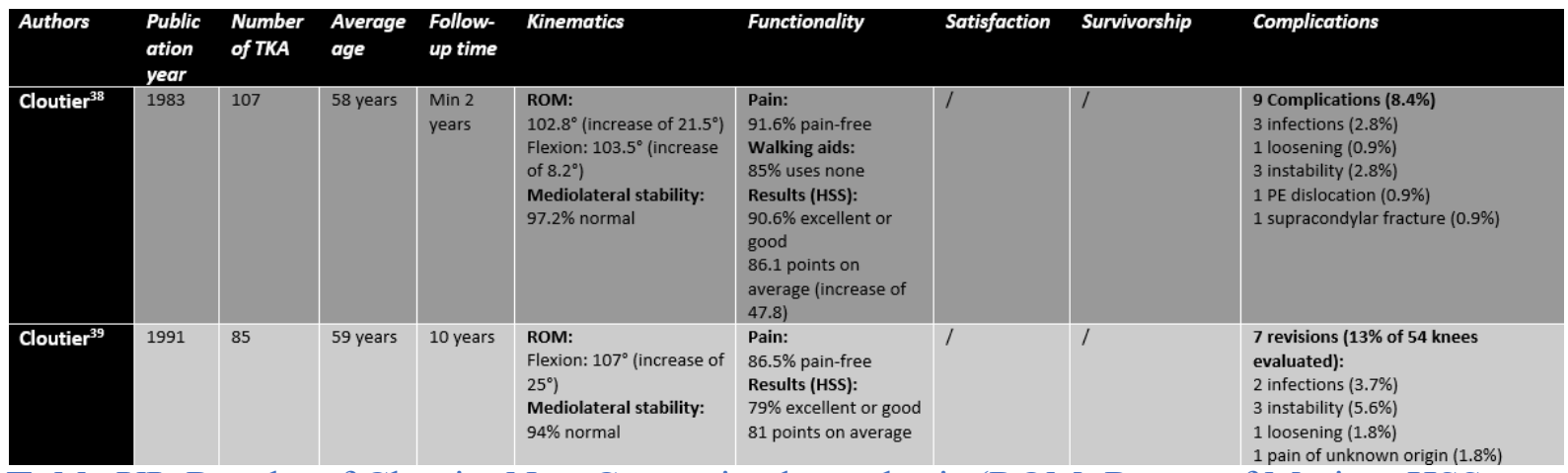

Table VII. — Results of LCS prosthesis (ROM : Range of Motion)

\begin{tabular}{|c|c|c|c|c|c|c|c|c|c|}
\hline Authors & $\begin{array}{l}\text { Public } \\
\text { ation } \\
\text { year }\end{array}$ & $\begin{array}{l}\text { Number } \\
\text { of TKA }\end{array}$ & $\begin{array}{l}\text { Average } \\
\text { age }\end{array}$ & $\begin{array}{l}\text { Follow- } \\
\text { up time }\end{array}$ & Kinematics & Functionality & Satisfaction & Survivorship & Complications \\
\hline $\begin{array}{l}\text { Buechel } \\
\text { and } \\
\text { Pappas }^{40}\end{array}$ & 1990 & 46 & I & 12 years & 1 & I & I & $\begin{array}{l}\mathbf{9 0 . 9 \%} \text { at } 12 \text { years } \\
\text { (cemented) } \\
\mathbf{1 0 0 \%} \text { at } 6 \text { years } \\
\text { (non-cemented) }\end{array}$ & 1 \\
\hline $\begin{array}{l}\text { Stiehl et } \\
\text { al. }^{41}\end{array}$ & 2006 & 324 & 62 & 5.7 years & $\begin{array}{l}\text { ROM: } \\
117^{\circ}\end{array}$ & I & I & $\begin{array}{l}79 \% \text { at } 14 \text { years } \\
\text { (endpoint: revision) } \\
89 \% \text { at } 10 \text { years }\end{array}$ & $\begin{array}{l}40 \text { failures (12.3\%): } \\
20 \text { loosening (6.1\%) } \\
4 \text { infection }(1.2 \%)\end{array}$ \\
\hline
\end{tabular}

Table VIII. - Results of Search prosthesis (ROM : Range of Motion ; KSS : Knee Society Score)

\begin{tabular}{|c|c|c|c|c|c|c|c|c|c|}
\hline Authors & $\begin{array}{l}\text { Public } \\
\text { ation } \\
\text { year }\end{array}$ & $\begin{array}{l}\text { Number } \\
\text { of TKA }\end{array}$ & $\begin{array}{l}\text { Average } \\
\text { age }\end{array}$ & $\begin{array}{l}\text { Follow- } \\
\text { up time }\end{array}$ & Kinematics & Functionality & Satisfaction & Survivorship & Complications \\
\hline $\begin{array}{l}\text { Jenny and } \\
\text { Jenny }{ }^{42}\end{array}$ & 1998 & 32 & 69 years & $2-3$ years & $\begin{array}{l}\text { ROM: } \\
\text { Flexion: } 102^{\circ}\end{array}$ & $\begin{array}{l}\text { Results (KSS): } \\
\text { Knee score } 89 \text { points } \\
\text { Functional score } 80 \\
\text { points }\end{array}$ & 1 & 1 & $\begin{array}{l}2 \text { Complications (6.3\%): } \\
1 \text { infection }(3.1 \%) \\
1 \text { patellar fracture (3.1\%) }\end{array}$ \\
\hline
\end{tabular}

The long-term follow-up studies reported a satisfaction rate of $93 \%$ and survivorship rates of $81.7 \%$ at 8.5 years and $69 \%$ at 11 years with severe pain or revision as endpoint. The survivorship rate and complications were similar to the Polycentric knee in long-term follow-up studies.

Dr. Townley developed the Townley Anatomic TKA in 1972 (table V) (36,37). It provided successful long-term clinical results. This was the first implant design to yield a low percentage of loosening ( $1 \%$ and $1.4 \%$ ) and both authors contributed it to their meticulous surgical technique. Pritchett resurfaced each patella. He also reported good clinical results with functional ligaments, even when there was a noticeable degeneration in the ACL. The KaplanMeier survivorship at 23 years was $89 \%$ with revision as the endpoint, which was remarkably higher than previous designs. The knees averaged 
Table IX. - Results of Hermes 2C prosthesis (ROM : Range of Motion ; AKSS : American Knee Society Score)

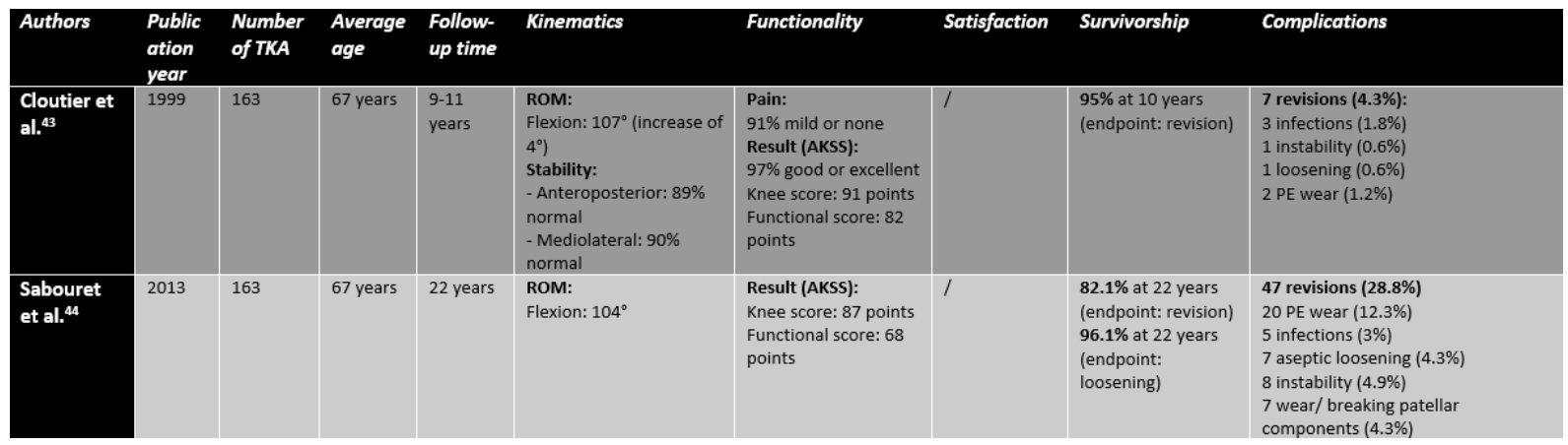

Table X. - Results of Vanguard XP prosthesis (ROM : Range of Motion ; KSS : Knee Society Score ;

PF-CAT : Physical Function Computerized Adaptive Test ; UCLA : University of Los Angeles at California activity score)

\begin{tabular}{|c|c|c|c|c|c|c|c|c|c|}
\hline Authors & $\begin{array}{l}\text { Public } \\
\text { ation } \\
\text { year }\end{array}$ & $\begin{array}{l}\text { Number } \\
\text { of TKA }\end{array}$ & $\begin{array}{l}\text { Average } \\
\text { age }\end{array}$ & $\begin{array}{l}\text { Follow- } \\
\text { up time }\end{array}$ & Kinematics & Functionality & Satisfaction & Survivorship & Complications \\
\hline $\begin{array}{l}\text { Christensen } \\
\text { et al. }\end{array}$ & 2017 & 78 & 65 years & $\begin{array}{l}12 \\
\text { months }\end{array}$ & $\begin{array}{l}\text { ROM: } \\
122^{\circ}\end{array}$ & PF-CAT: 43 & I & / & $\begin{array}{l}3 \text { revisions (5\%): } \\
1 \text { infection ( } 2 \%) \\
1 \text { ACL impingement (2\%) } \\
1 \text { loosening }(2 \%)\end{array}$ \\
\hline $\begin{array}{l}\text { Alnachoukati } \\
\text { et al. }\end{array}$ & 2018 & 146 & 68 years & $\begin{array}{l}12 \\
\text { months }\end{array}$ & $\begin{array}{l}\text { ROM: } \\
\left.121^{\circ} \text { (increase of } 5^{\circ}\right)\end{array}$ & $\begin{array}{l}\text { KSS function: } \\
89 \text { (increase of 31) } \\
\text { KSS total: } \\
96 \text { (increase of 48) } \\
\text { UCLA: } \\
6 \text { (increase of 2) }\end{array}$ & 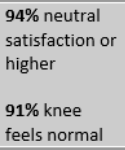 & / & $\begin{array}{l}2 \text { revisions }(1.4 \%) \text { : } \\
1 \text { severe pain and limited ROM }(0.7 \%) \\
1 \text { tibial component subsided }(0.7 \%)\end{array}$ \\
\hline Pelt et al. & 2019 & 141 & 64 years & 3 years & $\begin{array}{l}\text { ROM: } \\
123^{\circ} \text { (increase of } 2^{\circ} \text { ) }\end{array}$ & $\begin{array}{l}\text { Pain: } \\
16 \text { chronic pain } \\
\text { (11.3\%) } \\
\text { PF-CAT: } 45\end{array}$ & I & $88 \%$ at 3 years & $\begin{array}{l}19 \text { revisions (13.4\%) } \\
7 \text { loosening (5\%) } \\
3 \mathrm{ACL} \text { impingement }(2.1 \%) \\
4 \text { Pain }(2.8 \%)\end{array}$ \\
\hline
\end{tabular}

91 points on the American Knee Society Scoring system (AKSS).

Dr. Cloutier developed the Non-Constrained Natural TKA based on the Townley Anatomic TKA (table VI) (38,39). It showed good long-term clinical results with a low incidence of loosening $(0.9 \%$ and $1.8 \%)$. The author contributes this low incidence to the metal backing of the polyethylene insert. Nowadays, the metal-backed design has been abandoned because of the possibility of metallosis. No survivorship rate was reported. Using the Hospital for Special Surgery Knee score (HSS), they yielded an average of 86.1 points at 2 years minimum follow-up and 81 points at ten years follow-up.

The LCS TKA (table VII) was designed in the late 1970 s to prevent mechanical loosening and wear $(40,41)$. The two studies did not report on specific functional results. Stiehl et al. yielded a survivorship rate of $79 \%$ at 14 years with revision as endpoint with good clinical results. Buechel and Pappas reported a survivorship rate of $90.9 \%$ at twelve years for cemented knees and $100 \%$ at six years for uncemented knees. It should be noted that they had a low population size (46 TKAs). Loosening ( $6.1 \%$ of all knees) was the main reason for implant failures, despite of their design, and the infection rate (1.2\%) was higher than expected.

Only one article reported on the Search TKA (table VIII) (42). This study did not support the hypothesis that technical difficulties are increased in ACL preservation. The clinical and functional results were good, with a Knee score of 89 points and a functional score of 80 points using the Knee Society Scoring system (KSS), which is comparable to other implant designs. There was a low incidence of complications, but conclusions cannot be drawn from this because of the low number of TKAs included (32).

The Hermes 2C (table IX) used the same design principles as the Non-Constrained Natural TKA $(43,44)$. The two articles reported on the same patient 
population. The long-term studies (9-11 years and 22 years of follow-up) showed a good clinical and functional result, with a high survival rate. The knee score was 91 at 11 years and 87 at 22 years (AKSS). The functional score was 82 at 11 years and 68 at 22 years. They agree with Pritchett that degeneration of the ACL is no contraindication if the ligament is still functional. The main reason for failure was PE wear (12.3\% of all TKAs at 22 years), loosening was rare $(0.6 \%$ at $9-11$ years, $4.3 \%$ at 22 years).

We found three articles reporting on the Vanguard XP TKA (table X) (45-47). Christensen et al. reported a higher frequency of revisions $(5 \%)$ than expected. With these early clinical findings, they could not report any advantages of this prosthesis. Alnachoukati et al. reported great patient-reported satisfaction ( $94 \%$ were satisfied), function and short-term outcomes, with a low incidence of revisions (1.4\%). Pelt et al. reported a lower than expected revision-free survivorship $(88 \%$ at three years), with loosening being the leading cause $(5 \%$ of all TKAs).

\section{DISCUSSION}

Since the Polycentric knee implant was first proposed by Gunston in the late 1960s, a variety of BCR implants were introduced. The use of these implants remains controversial because of the technical difficulty, inconclusive benefit and increased risk of complications. This systematic review reports on nine different BCR implant designs, the oldest being introduced in the 1970s and the newest in the 2010s.

The aim of this review was to provide a comparison of clinical results between the different BCR implants and to evaluate whether a positive evolution can be seen. To the authors of this article's knowledge, this is the first study to compare the clinical results of the different BCR implants this extensively. We experienced difficulties quantifying the heterogenous outcome parameters of different studies. Different scoring systems are being used, which makes it difficult to properly compare clinical results. Theodoulou et al. reported the use of 86 different scoring systems in 438 articles, which makes it difficult to compare results (48). This shows the need for regularity in score system usage to improve comparability of clinician and patientreported outcome measures.

The designs developed in the beginning of the 1970s showed good functional results. However, the Polycentric, Geomedic and KodamaYamamoto prosthesis all showed a high incidence of complications, mostly attributed to loosening and infections. Throughout history, the incidence of infections decreased, as expected as the sterility improved. Many of these early designs had a kinematic conflict which led to their downfall. The inherent stability afforded by the conforming articular restriction interfered with kinematic freedom acquired by preserving the ACL. The Townley Anatomic TKA was the first design with a low incidence of loosening and a higher survivorship than previous designs. The Cloutier non-constrained knee showed similar results. Although the LCS TKA was designed to prevent loosening, they still reported a high incidence. The Search TKA had good functional results and a low incidence of complications. The results of the LCS TKA and Search TKA are weakened by the low number of patients included in these studies. The Hermes 2C showed similar results to the Cloutier non-constrained knee. After ten years they reported a high incidence of PE wear. The later designs were all condylar TKA designs, since the best results were achieved with this type of prosthesis.

The results of the new Vanguard XP prosthesis are mixed. All studies reported good functional results. Two studies reported a high incidence of failures, while Alnachoukati et al. report a low incidence of failure. The study with the longest follow-up reports a high rate of loosening. They hypothesize the cause to be multifactorial (malalignment, insufficient cementing, imprecise fitting and inadequate placement in inadequate bone or others).

Although it has shown clinical promise, the use of the BCR TKA with the new Vanguard XP design cannot be justified based on the results of these three studies. However, we only found three studies reporting on this newly introduced design. Therefore, it is possible that a substantial amount of these complications is caused by inexperience. In order to investigate the Vanguard XP TKA 
more thoroughly, a more extensive clinical trial is necessary. Preferably an independent randomized controlled trial with surgeons who are experienced with the device (to cancel out the potential learning curve). Christensen et al. already acknowledged their participation in such a study.

Jacofsky, Trecci and Osmani et al. all wrote systematic reviews comparing BCR TKA with other implant designs (CR, PS) without distinguishing between different BCR TKA designs (49-51). They all conclude that BCR TKA is promising, but its use is still debatable because of scarce long-term follow-up studies. Even though the kinematics closely resemble the native kinematics, the clinical outcomes do not significantly differ from other designs. Moreover, there is a higher complication rate with BCR TKA because of the added technical difficulties. However, the patient satisfaction rate is higher with BCR TKA. The short-term findings of the Vanguard XP TKA support these findings.

An alternative design with promising results might be the modular bi-unicondylar arthroplasty (Bi-UKA). This design preserves both cruciate ligaments and has shown to have the same kinematic advantages as BCR TKAs $(52,53)$. Short-term results show better functional results than TKAs being used nowadays (54-55). Different designs have been introduced trying to improve the results of TKA, long-term follow-up studies are needed to compare these different prostheses.

This study has several limitations. We did not grade the level of evidence of our included articles because of the paucity of literature on BCR TKA and the heterogeneity of outcome parameters between the different reports. We compared the clinical results of different prostheses. These results are not easily quantifiable. Moreover, if these clinical results differed, we could not assume causation, because of the multitude of different aspects that have changed throughout history within knee arthroplasty surgery.

Secondly, there is heterogeneity between the patient populations of the articles. This makes it more difficult to review the results. The KodamaYamamoto TKA was mainly used in Japan, while others were mainly used in North America and Europe. Patients in Japan may experience different results because of a variety of factors. Due to restrictions of our literature search to the English language, it is possible not all studies with results of BCR implants were included. Furthermore, publication or reporting bias cannot be ruled out since abstract-only articles were excluded.

The strengths of this review are that it is the first study to evaluate the different BCR TKA designs this extensively. It is also the first study to compare the results of previous BCR TKA designs with the early results of the Vanguard XP TKA. This study emphasizes the need for regularity in score system usage to improve comparability of clinician and patient-reported outcome measures. Finally, this study indicates the need for more research on this subject. Most notably, randomized controlled trials to evaluate long-term results.

In conclusion, BCR TKA may offer improved implant longevity, improved patient satisfaction and improved wear characteristics. The early designs already offered good functional results, but had a high rate of complications, especially loosening. Throughout history, these functional results improved, and the complications lessened. The short-term results of the latest BCR implant design, Vanguard XP, show good functional results, but a high rate of loosening. Based on the results of these three articles, the use of the Vanguard XP design cannot be recommended. Further research is necessary to assess the benefit of BCR TKA.

\section{REFERENCES}

1. Aubriot JH. Historique et evolution des protheses totales $\mathrm{du}$ genou. Cahier d'enseignement de la SOFCOT $\mathrm{n}^{\circ} 35$. Expans. Sci. Fr. Paris. 1989 ; 189 : 4.

2. Aubriot JH, Deburge A, Kenesi CL, Schramm P. La prothèse Guépar. Acta Orthop. Belg. 197339 : 257-259.

3. Norman Scott, W. Insall Scott. Surgery of the Knee. $6^{\text {th }}$ ed. Philadelphia (PA) : Elsevier ; 2017.

4. Makridis K, Karachalios T. A Brief History of Total Knee Arthroplasty. In : Karachalios T. (eds) Total Knee Arthroplasty. Springer, London (2015).

5. Long WJ, Bryce CD, Hollenbeak CS, Benner RW, Scott WN. Total knee replacement in young, active patients : long-term follow-up and functional outcome : a concise follow-up of a previous report. J. Bone Joint Surg. Am. 2014 ; 96(18) : 159.

6. Mont MA, John M, Johnson A. Bicruciate retaining arthroplasty. Surg. Technol. Int. 2012 ; 22 : 236-242. 
7. Parvizi J, Nunley RM, Berend KR. et al. High level of residual symptoms in young patients after total knee arthroplasty. Clin. Orthop. Relat. Res. 2014 ; 472 : 133137.

8. Stiehl JB, Komistek RD, Cloutier JM, Dennis DA. The cruciate ligaments in total knee arthroplasty : a kinematic analysis of 2 total knee arthroplasties. J. Arthroplasty $2000 ; 15(5): 545$.

9. Abdelbadie A, Toreih AA, Radwan MA. ACL status in arthroplasty patients, why not to preserve? SICOT J. 2018 ; $4: 1$.

10. Moro-Oka TA, Muenchinger M, Canciani JP, Banks SA. Comparing in vivo kinematics of anterior cruciateretaining and posterior cruciate-retaining total knee arthroplasty. Knee Surg. Sports Traumatol. Arthrosc. 2007 ; 15(1) : 93.

11. Pritchett J. Patient preferences in knee prostheses. J. Bone Joint Surg. Br. 2004 ; 86(7) : 979-982.

12. Parcells BW, Tria AJ Jr. The cruciate ligaments in total knee arthroplasty. Am. J. Orthop. 2016 ; 45(4) : 153-160.

13. Tria A. A Contemporary Bicruciate retaining Total Knee Arthroplasty. Seminars in Arthroplasty 2017 ; 28 : 65-70.

14. Gunston FH. Polycentric knee arthroplasty. J. Bone Joint Surg. Br. 1971 ; 53(B) : 272-5.

15. Bryan R, Richard S, Lowell F, Peterson A, Combs J. Polycentric Knee Arthroplasty: A review of 84 patients with more than one year follow-up. Clin. Orthop. Relat. Res. 1973 ; 94 : 136-139

16. Bryan RS, Peterson LF, Combs JJ. Polycentric knee arthroplasty. A preliminary report of postoperative complications in 450 knees. Clin. Orthop. Relat. Res. $1973 ; 94: 148-52$.

17. Gunston F, MacKenzie R. Complications of polycentric knee arthroplasty. Clin. Orthop. Relat. Res. 1976 ; 120 : 1117.

18. Ilstrup DM, Combs JJ, Bryan RS, Peterson LF, Skolnick MD. A statistical evaluation of polycentric total knee arthroplasties. Clin. Orthop. Relat. Res. 1976; 120 : 18-26.

19. Skollnick MD, Bryan RS, Peterson LF, Combs JJ, Ilstrup DM. Polycentric total knee arthroplasty. A twoyear follow-up study. J. Bone Joint Surg. Am. 1976 ; 58(6) : 743-748.

20. Manske P, DeBender J. Polycentric Total Knee Arthroplasty. South Med. J. 1977 ; 70(9) : 1088-1092.

21. Bloom J, Bryan R. Wide-track polycentric total knee arthroplasty: one year follow-up study. Clin. Orthop. Relat. Res. 1977 ; $128: 210-213$.

22. Bryan R, Peterson L. Polycentric total knee arthroplasty : a prognostic assessment. Clin. Orthop. Relat. Res. 1979; $145: 23-28$.

23. Cracchiolo A, Benson M, Finerman G, Horacek $\mathbf{K}$, Amstutz H. A prospective comparative clinical analysis of the first-generation knee replacements: polycentric vs. geometric knee arthroplasty. Clin. Orthop. Relat. Res. $1979 ; 145: 37-46$.
24. Lewallen D, Bryan RS, Peterson LF. Polycentric total knee arthroplasty. A ten-year follow-up study. J. Bone Joint Surg. Am. 1984 ; 66(8) : 1211-1218.

25. Thomas B, Cracchiolo A, Lee Y, Chow G, Navarro R, Dorey F. Total knee arthroplasty in rheumatoid arthritis. A comparison of the polycentric and total condylar prostheses. Clin. Orthop. Relat. Res. 1991 ; 265 : 129-136.

26. Yamamoto $S$. Total knee replacement with the KodamaYamamoto knee prosthesis. Clin. Orthop. Relat. Res. 1979 ; $145: 60-67$.

27. Yamamoto S, Nakata S, Kondoh Y. A follow-up study of an uncemented knee replacement : the results of 312 knees using the Kodama-Yamamoto prosthesis. J. Bone Joint Surg. Br. 1989 ; 71-B(3) : 505-508.

28. Coventry M, Upshaw J, Riley L, Finerman G, Turner R. Geometric total knee arthroplasty. II. Patient data and complications. Clin. Orthop. Relat. Res. 1973 ; 94 : 177-184.

29. Ilstrup D, Coventry M, Skolnick M. A statistical evaluation of geometric total knee arthroplasties. Clin. Orthop. Relat. Res. $1976 ; 120: 27-32$.

30. Skolnick M, Coventry M, Ilstrup D. Geometric total knee arthroplasty. A two-year follow-up study. J. Bone Joint Surg. Am. 1976 ; 58(6) : 749-753.

31. Hunter JA, Zoma AA, Scullion JE. et al. The Geometric knee replacement in polyarthritis. J. Bone Joint Surg. Br. 1982 ; 64(1) : 95-98.

32. Rand J, Coventry M. Ten-year evaluation of geometric total knee arthroplasty. Clin. Orthop. Relat. Res. 1988 ; $232: 168-173$.

33. Riley D, Woodyard JE. Long-term results of Geomedic total knee replacement. J. Bone Joint Surg. Br. 1985 ; 67(4), 548-550.

34. Ivarsson I, Myrnerts R, Tkaczuk H. Long-term followup of patients with geomedic prostheses. Arch. Orthop. Trauma Surg. 1986 ; 105(6) : 353-358.

35. van Loon C, Hu HP, Van Horn JR, De Waal Malefijt MC. The Geomedic knee prosthesis. A long-term follow-up study. Acta Orthop. Belg. 1993 ; 59(1) : 40-44.

36. Townley CO. The anatomic total knee resurfacing arthroplasty. Clin. Orthop. Relat. Res. 1985 ; 192 : 82-96.

37. Pritchett J. Bicruciate-retaining Total Knee Replacement Provides Satisfactory Function and Implant Survivorship at 23 Years. Clin. Orthop. Relat. Res. 2015 ; 473(7) : 23272333.

38. Cloutier J. Results of total knee arthroplasty with a nonconstrained prosthesis. J. Bone Joint Surg. Am. 1983 ; 65(7) : 906-919.

39. Cloutier J. Long-term results after nonconstrained total knee arthroplasty. Clin. Orthop. Relat. Res. $1991 ; 273$ : 63-65.

40. Buechel F, Pappas M. Long-term survivorship analysis of cruciate-sparing versus cruciate-sacrificing knee prostheses using meniscal bearings. Clin. Orthop. Relat. Res. 1990 ; 260, 162-169.

41. Stiehl J, Hamelynck K, Voorhorst P. International multicentre survivorship analysis of mobile bearing total knee arthroplasty. Int. Orthop. 2006 ; 30(3) : 190-199. 
42. Jenny J, Jenny G. Preservation of anterior cruciate ligament in total knee arthroplasty. Ach. Orthop. Traum. Surg. $1998 ; 118(3), 145-148$.

43. Cloutier J, Sabouret P, Deghrar A. Total knee arthroplasty with retention of both cruciate ligaments. A nine to elevenyear follow-up study. J. Bone Joint Surg. Am. 1999 ; 81(5) : 697-702.

44. Sabouret P, Lavoie F, Cloutier JM. Total knee replacement with retention of both cruciate ligaments. Bone Joint $J$. 2013 ; 95-B(7) : 917-922.

45. Christensen J, Brothers J, Stoddard G. et al. Higher Frequency of Reoperation With a New Bicruciate-retaining Total Knee Arthroplasty. Clin. Orthop. Relat. Res. 2017 ; 475(1) : 62-69.

46. Alnachoukati O, Emerson R, Diaz E, Ruchaud E, Ennin K. Modern Day Bicruciate-Retaining Total Knee Arthroplasty: A Short-Term Review of 146 Knees. J. Arthroplasty 2018 ; 33(8) : 2485-2490.

47. Pelt C, Sandifer P, Gililland J, Anderson M, Peters C. Mean Three-Year Survivorship of a New BicruciateRetaining Total Knee Arthroplasty: Are Revisions Still Higher Than Expected? J. Arthroplasty 2019; 34(9) : 1957-1962.

48. Theodoulou A, Bramwell D, Spiteri A, Kim S, Krishnan J. The use of scoring systems in knee arthroplasty: a systematic review of the literature. The Journal of Arthroplasty $2016 ; 31(10): 2364-2370$.

49. Jacofsky D. Bicruciate-Retaining Total Knee Arthroplasty. In: Bellemans J., Ries M.D., Victor J.M. Total Knee Arthroplasty. Springer, Berlin, Heidelberg

50. Trecci, A. Bicruciate retaining. Ann. Transl. Med. 2016 ; 4(7), 128.

51. Osmani F, Thakkar S, Collins K, Schwarzkopf R. The utility of bicruciate-retaining total knee arthroplasty. Arthroplasty today 2017 ; 3(1) : 61-66.

52. Baumann F, Bahadin O, Krutsch W. et al. Proprioception after bicruciate-retaining total knee arthroplasty is comparable to unicompartmental knee arthroplasty. Knee Surg. Sports Traumatol. Arthrosc. 2017 ; 25 : 1697-1704.

53. Banks SA, Fregly BJ, Boniforti F, Reinschmidt C, Romagnoli S. Comparing in vivo kinematics of unicondylar and bi-unicondylar knee replacements. Knee Surg. Sports Traumatol. Arthrosc. 2005 ; 13(7) : 551-556.

54. Confalonieri N, Manzotti A, Cerveri P, Momi E. Biunicompartmental versus Total Knee Arthroplasty: A Matched Paired Study with Early Clinical Results. Archives of Orthopaedic and Trauma Surgery 2009 ; 129(9) : 1157163.

55. Biazzo A, Manzotti A, Confalonieri N. Bi-unicompartmental versus total knee arthroplasty: long term results. Acta Orthop. Belg. 2018 ; 84(3) : 237-244. 